Original Articles

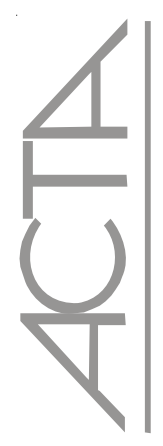

\title{
Evaluation of expected outcomes of nursing interventions to address the nursing diagnosis of fatigue among patients with congestive heart failure*
}

\author{
Avaliação das intervenções e dos resultados esperados para o diagnóstico de enfermagem Fadiga, em \\ portadores de Insuficiência Cardiaca
}

Evaluación de las intervenciones y de los resultados esperados para el diagnóstico de enfermería Fatiga, en pacientes con Insuficiencia Cardiaca Congestiva

\author{
Cinthia Calsinski de Assis ${ }^{1}$, Alba Lúcia Bottura Leite de Barros ${ }^{2}$, Marcela \\ Zanatta Ganzarolli ${ }^{3}$
}

\begin{abstract}
Objective: To evaluate expected outcomes of nursing interventions to address the nursing diagnosis of fatigue. Methods: A cross-sectional quasi-experimental design was used. The sample consisted of 30 coronary care unit in-patient with congestive heart failure and fatigue. A specific tool designed for this study was used to collect specific data on outcomes of nursing interventions to manage the nursing diagnosis of fatigue. Results: Nursing interventions to manage patients' fatigue had positive outcomes. Conclusion: The use of the nursing process to identify the nursing diagnosis of fatigue, design and implement specific nursing interventions, and evaluate patient outcomes leads to quality nursing care.
\end{abstract}

Keywords: Heart failure, congestive; Nursing diagnosis; Fatigue; Patient care planning; Nursing process

\section{RESUMO}

Objetivo: Avaliar os resultados alcançados após intervenções de enfermagem para o diagnóstico de enfermagem Fadiga. Métodos: Estudo, quase-experimental, tempo série e transversal, realizado em Hospital Universitário por meio da implementação de intervenções e avaliação diária dos resultados em 30 pacientes com diagnóstico de insuficiência cardíaca e de enfermagem fadiga, internados na Unidade de Cardiologia e UTI Coronária. Foi elaborado um instrumento de coleta de dados composto por intervenções e resultados de enfermagem. Resultados: Foi observada boa evolução de todos os indicadores avaliados. As intervenções de enfermagem atingiram satisfatoriamente os resultados esperados. Conclusão: Ao sistematizar a assistência de enfermagem, alcançamos resultados favoráveis em suas evidências clínicas.

Descritores: Insuficiência cardíaca congestiva; Diagnóstico de enfermagem; Fadiga; Planejamento de assistência ao paciente; Processos de enfermagem

\section{RESUMEN}

Objetivo: Evaluar los resultados alcanzados después de las intervenciones de enfermería para el diagnóstico de enfermería Fatiga. Métodos: Se trata de un estudio, cuasi-experimental, tiempo serie y transversal, realizado en un Hospital Universitario por medio de la implementación de intervenciones y evaluación diaria de los resultados en 30 pacientes con diagnóstico de insuficiencia cardiaca y de enfermería fatiga, internados en la Unidad de Cardiología y UCI Coronaria. Fue elaborado un instrumento de recolección de datos compuesto por intervenciones y resultados de enfermería. Resultados: Fue observada buena evolución de todos los indicadores evaluados. Las intervenciones de enfermería alcanzaron de manera satisfactoria los resultados esperados. Conclusión: Al sistematizar la asistencia de enfermería, alcanzamos resultados favorables en sus evidencias clínicas.

Descriptores: Insuficiencia cardiaca congestiva; Diagnóstico de enfermería; Fatiga; Planificación de atención al paciente; Procesos de enfermería

\footnotetext{
${ }^{*}$ Study carried out at Cardiology Init and Intensive Care Unit of Hospital São Paulo.

${ }^{1}$ Post-graduand at the Federal University of Sao Paulo - UNIFESP - Sao Paulo (SP), Brazili:

${ }^{2}$ Full Professor at the Nursing Department - Federal University of Sao Paulo - UNIFESP - Sao Paulo (SP), Brazil.

${ }^{3}$ Post-graduand at the Federal University of Sao Paulo - UNIFESP - Sao Paulo (SP), Brazil.
} 


\section{INTRODUCTION}

Congestive heart failure is defined as a clinical syndrome in which a structural or functional disorder of the heart results in the decrease of the ventricle's capacity to eject blood and/or be filled with blood in the physiological filling pressures ${ }^{(1)}$. This disorder can happen due to a diminished capacity of myocardial contraction or to an excess of pressure/volume imposed on the heart ${ }^{(2)}$.

In Brazil, there are no epidemiological studies related to congestive heart failure but, according to other countries, it can be estimated that up to 6.4 million Brazilian people have this condition. As shown by data collected from the SUS (Brazilian Single Health System), from the Health Ministry, in 2000, around 398 thousand hospitalizations occurred due to congestive heart failure, with 26 deaths. Around a third of the people hospitalized in the SUS with a heart condition has congestive heart failure. Besides, among patients over 60 , congestive heart failure is the main hospitalization cause. Therefore, congestive heart failure is turning into a severe public health problem all over the world. Besides high hospital costs for emergency services, congestive heart failure causes a visible loss in quality of life, often resulting in early retirement and a high socioeconomic cost for the country ${ }^{(3)}$.

Modern nursing is attempting to create its own body of knowledge, granting the profession a scientific action pattern. This attempt has resulted in the Nursing Work Process, which is used as a systematic care delivery method, aimed at creating conditions to help in an individualized way, supporting greater integration between nurses and patients, families, the community and the multiprofessional team, favoring the improvement in care quality ${ }^{(4)}$.

The nursing work process has been defined in Brazil as the "dynamics of systemized and inter-related actions, aiming at care delivery to human beings". In this proposal, the process was divided in: history, diagnosis, care plan, prescription, evolution and prognosis of nursing work (5). Since that moment, several Brazilian authors have been calling attention to the application of this process as a method to systemize nursing care, in hospitals as well as in outpatient care ${ }^{(6)}$.

Nursing care planning is based on nursing diagnoses, identified through a high level of intellectual skills and knowledge. They constitute the basis for planning, intervention and patient assessment ${ }^{(7-8)}$.

As heart diseases are responsible for the highest number of deaths in Brazil, the amount of patients with the nursing diagnosis of "Fatigue" is equally significant. Hence, evaluating the interventions proposed in the NIC (Nursing Intervention Classification) classification ${ }^{(9)}$ and the results grouped in the NOC (Nursing Outcomes Classification) ${ }^{(10)}$ will favor care quality assessment through observed and systematically measured results, thus contributing to knowledge development and solidification in nursing science.

Due to the importance of congestive heart failure, it is believed that the care nurses deliver to these patients must be planned, systemized and based on scientific knowledge. This kind of action aims to deliver proper nursing care to the patient, constructed through the detection of problems and survey of nursing diagnoses. The proper identification of the presented problems permits appropriate care planning, aiming to achieve the expected nursing results ${ }^{(10)}$ by implementing the nursing interventions selected on the basis of the identified diagnosis ${ }^{(9)}$.

This article aims to assess the results, according to the NOC classification, after performing interventions suggested by the NIC for the nursing diagnosis Fatigue, in patients with congestive heart failure.

\section{METHODS}

Quasi-experimental and cross-sectional time series study, conducted at a University Hospital, with the implementation of interventions and daily assessment of results.

The convenience sample determined a study population that comprised all patients clinically treated between April and July 2002 ( $n=30)$ with congestive heart failure, hospitalized at the Cardiology Unit and Intensive Care Unit of the research institution.

In compliance with current rules, the study proposal was approved by the Research Ethics Committee at the institution, before the beginning of data collection. The approval for participation by the research subjects was formalized by signing the free and informed consent term, in line with legal orientations.

The following patients were excluded: age under 18, said that they did not want to participate in the study, disagreed with the free and informed consent term, were not consistent or sedated, were transferred from a hospitalization unit.

Two patients from the sample died, three did not want to participate in the study and one was transferred to another unit $(16.6 \%)$.

For data collection among patients with congestive heart failure of functional type I, II, III and IV, we used the data collection instrument used at the Cardiology Unit, already validated in previous studies ${ }^{(11)}$. This instrument uses the following models as references: Horta, Orem, Epidemiological Risk and Biomedical ${ }^{(4)}$, supported by the identification of the Nursing Diagnosis ${ }^{(12)}$ presented by the patients who suffered from the pathology underanalysis.

The author identified the diagnosis through anamnesis and a physical exam. Among the identified diagnoses, Fatigue was found in more than $90 \%$ of the patients, which gave rise to the interest to evaluate the nursing interventions and results for this diagnosis. 
Based on literature ${ }^{(9-10)}$, we chose the results and nursing interventions that were most proper for the participants' profile. After this selection, we designed a clinical evaluation instrument.

For the nursing diagnosis under analysis, we selected the nursing interventions ${ }^{(10)}$ : Energy Control and Exercise Promotion. This selection obeyed to the criterion of greater importance for the diagnosis.

The expected outcome ${ }^{(9)}$ chosen for these interventions was: Activity tolerance. This result comprised of the following indicators: oxygen saturation in response to the activity inside expected parameters (IEP), heart beat in response to the activity IEP, blood pressure in response to the activity IEP, skin color within normal patterns (WNP), daily life activities performed IEP, ability to speak during the exercise, ability to acknowledge energy limitations, use energy preservation techniques, adapt life style based on the energy level, maintain appropriate nutrition, show concentration IEP, display normal appetite, demonstrate interest in displaying the correct energy level.

The clinical evaluation instrument consisted of the diagnosis definition under discussion, its defining characteristics and related factors, the nursing activities suggested by the interventions, and the indicators to be evaluated as listed in the result.

The activities were prescribed and performed by the researcher during the night shift and by the unit nurses and/or nursing aids in the morning or afternoon periods.

For patient evaluation, a scale was used that designates a numeric value to each evaluated item, according to the commitment degree, as follows:

1. Highly committed

2. Substantially committed

3. Mildly committed

4. Slightly committed

5. Not committed

However, in some cases, due to the lack of evaluation in the graded scale, one of two values was selected for the evaluated item:
1. Presence of or commitment

5. Lack of or non-commitment

For the result analysis, we compared the maximum score (5) for each item on the first and in the seventh day of hospitalization. We used these seven days of hospitalization to compare the scores, as this was the arithmetic average of patients' hospitalization time, measured in days.

All patients received the nursing activities, as these had been prescribed and were checked in the control sheet of the coronary ICU and of the Cardiology Ward.

\section{RESULTS}

Two subjects $(6.6 \%)$ were between 20 and 35 years old, three $(10 \%)$ between 36 and 50 years old, $18(60 \%)$ between 51 and 65 years old, and seven (23\%) older than 66 years. Most patients were men $(60 \%, n=18)$.

For the naming of the diagnosis Fatigue, nine defining characteristics (DC) were identified in the population under analysis. All subjects presented the DC need for additional energy, $83 \%$ presented inability to maintain routines and $70 \%$ said they lacked energy. Table 1 displays the occurrence and distribution of the DCs in the study subjects.

Table 1 - Defining characteristics of the nursing diagnosis Fatigue, identified in patients hospitalized in the Cardiology Unit and Coronary ICU. São Paulo, 2002

\begin{tabular}{lcc}
\hline Defining characteristics & $\mathbf{n .}^{\mathbf{0}}$ & $\mathbf{0}$ \\
\hline Perceived need for additional energy & 30 & 100 \\
Inability to maintain usual routines & 25 & 83 \\
Verbalization of lack of energy & 21 & 70 \\
Increase in physical complaints & 15 & 50 \\
Emotional instability/irritation & 18 & 60 \\
Lethargic and/or agitation & 18 & 60 \\
Compromised concentration & 21 & 70 \\
Decreased performance & 7 & 23 \\
Disinterest, introspection & 17 & 57 \\
\hline
\end{tabular}

Table 2 - Evolution of maximum score (5) for each indicator of the Activity Tolerance result on the first and seventh day of hospitalization. São Paulo, 2002.

\begin{tabular}{|c|c|c|c|c|}
\hline Indicators & $\begin{array}{l}\text { D1 } \\
\text { n. }^{\circ}\end{array}$ & $\%$ & $\begin{array}{l}\text { D7 } \\
\text { n. }^{\circ}\end{array}$ & $\%$ \\
\hline Tailoring life style to the energy level & - & - & 5 & 17 \\
\hline Skin color inside normal patterns & 5 & 17 & 13 & 43 \\
\hline Execution of daily living activities & - & - & 20 & 68 \\
\hline Ability to speak during the exercise & 5 & 17 & 13 & 43 \\
\hline Acknowledging energy limitations & 22 & 75 & 25 & 83 \\
\hline Using energy preservation techniques & - & - & 22 & 75 \\
\hline Keeping the right nutrition & 12 & 40 & 25 & 83 \\
\hline Show normal appetite & 5 & 17 & 18 & 60 \\
\hline Show concentration & 20 & 68 & 29 & 98 \\
\hline Heart beat in response to the activity & 11 & 38 & 22 & 75 \\
\hline Respiratory frequency and rhythm in response to activity & - & - & 21 & 70 \\
\hline Oxygen saturation in response to activity & 12 & 40 & 15 & 50 \\
\hline
\end{tabular}


The main nursing interventions were classified as "dependent activities" or started by physicians and "independent activities" or started by nurses ${ }^{(10)}$. We noticed that, for the execution of the suggested activities for the Energy Promotion intervention, 100\% of the activities were independent. For the Energy Control intervention, $75 \%$ of the activities were independent.

As to the scores designed to each indicator of the result Activity Tolerance, all evaluated items presented an improvement in the second evaluation, as shown in Table 2.

\section{DISCUSSION}

The indicators for the Activity Tolerance result will be discussed individually, comparing the first and seventh hospitalization day.

Tailoring life style to the energy level: situation in which the patient tailors his/her activities to the available energy level. Tailoring means to fit one thing to the other, shaping, make proper, and adjust. By analyzing the patient's situation during the hospitalization, it can be concluded that he/she needs adaptation in several aspects. On the first hospitalization day, no patient presented this adaptation. However, through the application of the proposed interventions, on day seven, $17 \%$ of the patients said they were adapted.

Skin color within the normal patterns: depends on the pigments in the basal layer of the epidermis and its concentration, thickness and microcirculation network ${ }^{(13)}$. It was noticed that, on the first hospitalization day, only $17 \%$ of the patients were evaluated with score 5 , against $43 \%$ on day seven.

Execution of daily living activities: ability to perform routine activities, such as brushing teeth, bathing and eating. It was noticed that, on the first hospitalization day, no patient presented score 5 , and $85 \%$ presented score 1 , which represented the changes in rest. By applying the proposed intervention, on day seven of the hospitalization, only $23 \%$ of the patients presented score 1 .

Ability to speak during the exercise: it is comprised of performing an exercise activity and speaking at the same time. The diminished heart beat due to congestive heart failure produces generalized manifestations, because the blood that reaches the tissues and organs is not enough to offer the necessary oxygen amount. This can result in dizziness, confusion, fatigue and, mainly, activity intolerance. Thus, on the first day of hospitalization, 17\% of the patients were able to speak while exercising while, on day seven, $43 \%$ of the patients talked during an activity considered as an exercise ${ }^{(14)}$.

Acknowledging energy limitations: state in which the patient can acknowledge the intensity at which he/she can or cannot perform an activity. The disproportion between the entrance and need of oxygen and other nutrients in tissues is one of the main characteristics of congestive heart failure. In the absence of these elements, there is a significant drop in patients' physical ability, from the simplest to the most complex ${ }^{(15)}$. This acknowledgement was demonstrated by $75 \%$ of the patients on the first day of hospitalization, and by $83 \%$ on day seven.

Using energy preservation techniques: this DC was only evaluated after possible actions had been taught to the patients, such as brushing the teeth seated, or sitting down to bathe, for example. On the first day of hospitalization, no patient knew about the energy preservation techniques while, on day seven, $75 \%$ of the patients used the techniques they were taught.

Keeping the right nutrition: it is the intake of several nutrients in proper amounts for body needs, such as vitamins and minerals, with a view to appropriate metabolic functioning ${ }^{(15)}$. This indicator was evaluated through the identification of the food groups consumed by the patients and the calculation of their body mass index (BMI). On the first day of hospitalization, $40 \%$ of the patients presented score 1 while, on day seven, $83 \%$ presented score 5 .

Show normal appetite: it was evaluated if the appetite was normal for the individual, comparing him/her with him-/herself on other days, when possible. The family's help was requested when needed. Anorexia and nausea are caused by the congestion of belly organs, causing a false feeling of satisfaction or abdominal discomfort, and this can end up causing a decrease in the desire to eat in patients with congestive heart failure ${ }^{(14)}$. On the first day of hospitalization, only $17 \%$ of the patients showed score 5 while, on day seven, $60 \%$ of the patients presented this score.

Show concentration: brain hypoxia caused by low heart beat can originate hypoxic encephalopathy, noticing irritation, loss of attention and/or concentration and agitation $^{(15)}$. In the evaluation of this indicator, $68 \%$ of the patients received score 5 on the first day of hospitalization, against $98 \%$ on day seven.

Heart beat in response to the activity within normal patterns: we found $38 \%$ of the patients with score 5 on the first day of hospitalization, and $75 \%$ on day seven.

Heart beat and respiratory rhythm in response to the activity within normal patterns: on the first day of hospitalization, none of the patients reached score 5 , against $70 \%$ on day seven.

Oxygen saturation in response to the activity within normal patterns: oxygen reception happens primarily in the lungs, constituting the first step in the process of offering oxygen to the tissues. Once received, the oxygen is transported in the blood, dissolved in the plasma $(2 \%)$ or combined with the hemoglobin $(98 \%)^{(14)}$. On the first day of hospitalization, $40 \%$ of the patients presented saturation within normal patterns and, after the 
interventions, $50 \%$ of them presented normal patterns on day seven.

A good evolution in all evaluated indicators was noticed. Nursing interventions reached the expected results.

When comparing these study results with similar papers, conclusions appear that support this research's conclusions. In a study about the activity tolerance diagnosis, only one patient $(3.2 \%)$ did not present the expected evolution related to the scores/days of hospitalization ${ }^{(16)}$. In another research, on the nursing diagnosis Excessive fluid volume, on the first day of hospitalization, $50 \%$ of the patients reached score 5 , against $82 \%$ on day seven, also demonstrating an expected evolution ${ }^{(17)}$.

\section{CONCLUSION}

Patients are limited by the clinical characteristics of congestive heart failure, significantly decreasing their quality of life.

It is obvious that patients' clinical improvement cannot only be attributed to the performed nursing actions, because their positive evolution results from a set of factors, such as nursing activities and pharmaceutical therapy, and the limitations of this study should also be taken into account.

We consider that the care delivered to subjects hospitalized for congestive heart failure involves multiple professionals and factors.

After analyzing the data, as well as the similarities found in other studies, the improvement of nursing diagnoses through the classification of interventions and results becomes evident.

We can conclude that the proposed nurse interventions successfully lead to the result suggested for the diagnosis under study.

When the patient receives a better planned nursing care, based on scientific knowledge and evidence, as well as on nursing classifications, the evaluation of the improvement in the obtained results shows the efficiency of the proposed interventions.

We suggest the creation of suggested care protocols for the prevailing nursing diagnosis at clinical and surgical units, thus turning care systemization into a feasible and clearly effective tool in patient care.

\section{REFERENCES}

1. Felker GM, Adams KF Jr, Konstam MA, O`Connor CM, Gheorghiade M. The problem of decompensated heart failure: nomenclature, classification, and risk stratification. Am Heart J. 2003; 145(2 Suppl):S18-25.

2. Braunwald E, Sobel BE. Heart disease. A text book of cardiovascular medicine. Philadelphia: Elsevier Saunders; 2005.

3. II diretriz para o diagnóstico e tratamento da insuficiência cardíaca. Arq Bras de Cardiol. 2002; 79(Suppl 4):1-30.

4. Barros ALBL. OTrabalho docente assistencial de enfermagem no Hospital São Paulo da UNIFESP/EPM [tese]. São Paulo: Universidade Federal de São Paulo, Escola Paulista de Medicina; 1998.

5. Horta WA. Processo de enfermagem. São Paulo: Editora Pedagógica e Universitária; c1979.

6. Campedelli MC, organizadora. Processo de enfermagem na prática. São Paulo: Ática; 1989.

7. Clark J, Lang N. Nursing's next advance: an internal classification for nursing practice. Int Nurs Rev. 1992; 39(4):109-11, 128.

8. Bulechek GM, McCloskey JC. Defining and validating nursing interventions. Nurs Clin North Am. 1992; 27(2): 289-99.

9. McCloskey JC, Bulechek GM, editors. Nursing Intervention Classification (NIC): Iowa intervention project. St. Louis: Mosby; 2004.

10. Johnson M, Maas M, Moorhead S,editors. Nursing outcomes classification (NOC). St. Louis: Mosby; 2004.

11. Michel JLM, Barros ALBL. A utilização da entrevista em grupo focal para validação de conteúdo de um instrumento de coleta de dados de enfermagem. Acta Paul Enfermagem. 2000; 13(N Esp Pt 2): 138-42.

12. NANDA - Nursing Diagnoses: definitions and classification 2001-2002. St. Louis: NANDA International; 2006.

13. Bates B, Hockelman RA. Propedêutica médica. Rio de Janeiro: Guanabara-Koogan; 2005.

14. Ramos Jr J, Semiotécnica da observação clínica. São Paulo: Sarvier; 1998.

15. Guyton AC, Jones CE, Coleman T.G. Tratado de fisiologia médica. 9a ed. São Paulo: Interamericana; 1997.

16. Rodrigues FG, Andrade FC. Avaliação do resultado de enfermagem tolerância à atividade (NOC) em pacientes portadores de ICC tipo funcional III e IV após as atividades de enfermagem realizadas (NIC).In: $13^{\circ}$. Congresso de Iniciação Científica da Universidade Federal de São Paulo; 2005.

17. Lopes JL, Barros ALBL. Validação das principais intervenções de enfermagem da Nursing Intervention Classification (NIC) e dos resultados sugeridos pela Nursing Outcomes Classification (NOC) para o diagnóstico de enfermagem 'Excesso de Volume de Líquidos'. In: X Congresso de Iniciação Científica (PIBIC), 2002, São Paulo. Anais do PIBIC 2002. São Paulo: Pró-Reitoria de Graduação da UNIFESP e Conselho Nacional de Desenvolvimento Científico e Tecnológico, 2002. v. 1. p. 92-93. 